\title{
Multipl Sklerozlu Hastalarda Güncel Diyet Yaklaşımları
}

\section{Current Dietary Approaches in Patients with Multiple Sclerosis}

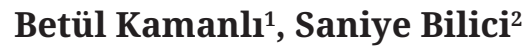

Geliş tarihi/Received: 03.08.2021 • Kabul tarihi/Accepted: 05.01.2022

\section{ÖZET}

Multipl Skleroz (MS); nöroinflamatuvar, demiyelinize, otoimmün merkezi sinir sistemi hastalığıdır. MS ile ilişkili hastalık süreci; inflamasyon, sinir liflerini koruyan ve çevreleyen membran yağ bileşeni, miyelin yıkımı ve/veya hasarı ile sonuçlanmaktadır. Beslenme alışkanlıklarının ve yaşam tarzının MS seyrini etkileyip etkilemediği sorusu hala tartışma konusudur. Diyet faktörleri ve bireyin yaşam tarzı alışkanlıkları, hem atak ve iyileşmelerle giden MS (Relapsing-remitting) hem de birincil ilerleyici MS'de (primer progresif) hastalığın inflamatuvar durumunu modüle ederek semptomları iyileştirebilir veya şiddetlendirebilir. Bu durum hücresel düzeyde hem metabolik hem de inflamatuvar yolları ve kommensal bağırsak mikrobiyatasının bileşimini kontrol ederek oluşmaktadır. Sebzeler, meyveler, kurubaklagiller, balık, prebiyotikler ve probiyotiklerden zengin düşük enerjili diyetlerin ve düzenli yapılan egzersizin; nükleer reseptörler ve enzimler üzerinde olumlu etki oluşturduğu, oksidatif metabolizmayı ve proinflamatuvar molekülleri düzenlediği ve sağlıklı simbiyotik bağırsak mikrobiyatasının sürdürülmesi ve restore edilmesine katkı sağladığı gösterilmiştir. Özellikle Akdeniz tipi beslenme modeli gibi diyet müdahalelerinin; bağışıklık düzenleyici ilaçların olası yan etkilerini ve kronik yorgunluk sendromunun semptomlarını hafifletmede, semptomların nüksetmesini ve hastalığın ilerlemesini önlemede yarar sağladığı bildirilmektedir. MS hastalarının diyetlerindeki sağlıklı beslenmeye yönelik değişiklikler hastaların hem yaşam kalitesini artırmakta hem de fiziksel ve mental iyileşme sağlamaktadır. Bu derlemede, farklı diyet modellerinin MS üzerindeki etkisinin değerlendirilmesi amaçlanmıştır.

Anahtar kelimeler: Diyet modeli, multipl skleroz, Akdeniz diyeti, Swank diyeti, ketojenik diyet

\begin{abstract}
Multiple Sclerosis (MS); is a neuroinflammatory, demyelinated autoimmune central nervous system disease. MS-related disease process result in inflammation, membrane fat component which protects and surrounds nerve fibers, myelin destruction and/or damage. The question of whether nutrition habits and lifestyle affect the course of MS is still a matter of debate. Dietary factors and lifestyle can improve or aggravate MS symptoms by modulating the inflammatory state of the disease in both relapsing-remitting or primary progressive MS. This state occurs by controlling both metabolic and inflammatory pathways in human cell and the composition of commensal gut microbiata. It has been shown that lowcalorie diets rich in vegetables, fruits, legumes, fish, prebiotics and probiotics and routine exercise have a positive effect on nuclear receptors and enzymes, regulate oxidative metabolism and proinflammatory molecules and contribute to the maintenance and restoration of healthy symbiotic intestinal microbiata. It has been reported that dietary interventions such as the Mediterranean diet model are beneficial in alleviating the possible side effects of immunomodulatory drugs and the symptoms of chronic fatigue syndrome, preventing recurrence of symptoms and progression of the disease. Changes in the
\end{abstract}

1. İletişim/Correspondence: Bozok Üniversitesi Araştırma ve Uygulama Hastanesi Beslenme ve Diyet Birimi, Yozgat, Türkiye

E-posta: betul.patat88@hotmail.com • @ https://orcid.org/0000-0002-0588-9502
2. Gazi Üniversitesi, Sağlık Bilimleri Fakültesi, Beslenme ve Diyetetik Bölümü, Ankara, Türkiye • • https://orcid.org/0000-0002-1235-0329 
diets of MS patients towards healthy nutrition both increase the quality of life and provide physical and mental recovery of patients. This review aims to evaluate the effect of different diet models on Multiple Sclerosis.

Keywords: Diet model, multiple sclerosis, Mediterranean diet, Swank diet, ketogenic diet

\section{GíRIŞ}

Multipl Skleroz, merkezi sinir sisteminin en yaygın görülen,inflamatuvarvedemiyelinizanbozukluğudur. Yorgunluk, yürüme bozuklukları, spazmlar, bilişsel problemler, idrar inkontinansı, cinsel bozukluklar, ağrı, duygusal veya duygudurum bozuklukları, görme problemleri, baş dönmesi, titreme gibi çeşitli semptomlar ile karakterizedir. Otoimmün bir hastalık olan MS'in kesin nedeni bilinmemektedir. Ancak genetik ve çevresel faktörlerin MS'in patogenezinde rol oynadığı düşünülmektedir $(1,2)$. Genetik faktörler, geçirilmiş viral enfeksiyon ve/veya reaktivasyon (Ebstein-Barr virüsü), güneş maruziyeti, D vitamini yetersizliği, hava kirliliği, sigara ve tütün kullanımı, çocukluk çağı obezitesi, erken menarş, gebelik ve emziklilik hastalık için bilinen risk faktörleridir. MS'li hastalarda ise beslenme alışkanlıkları, diyet örüntüsü ve bağırsak mikrobiyatasının yaşam kalitesini etkileyen önemli faktörler olduğu belirtilmektedir (3).

Bazı MS hastaları ciddi sakatlık yaşarken, bazılarında ise hafif semptomlar görülmektedir. MS seyrinin bu heterojenliği son ylllarda değiştirilebilen diyetsel faktörlere olan ilgiyi arttırmıştır (2). Beslenme, MS hastalarında hem hastalığın patogenezinde hem de tedavisinde önemlidir. Ancak MS riskini azaltan ve prognozunu olumlu yönde etkileyen herhangi bir diyet müdahalesinin güçlü ve doğrudan etkisini gösteren kanıtlar henüz yetersizdir (4).

Multipl skleroz, için etkinliği kanıtlanmış spesifik bir diyet bulunmamaktadır. Ancak ketojenik diyet, Swank diyeti, Mc Dougall diyeti, Paleo diyeti gibi farklı diyet modellerinin MS'de mortalite, yaşam kalitesi ve yorgunluk düzeyi üzerinde yararlı etkilerinin bulunduğu bildirilmektedir (5).

\section{Ketojenik Diyet}

Ketojenik diyet (KD); yüksek yağll, düşük proteinli ve düşük karbonhidratlı bir diyettir (6). Farklı oranlarda ketojenik diyetler olmakla birlikte klasik ketojenik diyet 4:1 oranında (her 1 gram protein+karbonhidrat için 4 gram yağ) oluşmaktadır. Orta Zincirli Trigliserit (MCT) Ketojenik Diyette enerjinin \%45’i yağ, \%20 'si protein ve \%35'i karbonhidratlardan oluşmakta olup, enerjinin \%40-60’ı MCT yağı tarafindan sağlanmaktadır. Modifiye Atkins Diyeti ise 10-20 g/ gün karbonhidrat ile sinırlandırılmış olup, 1-2:1 yağ/ protein ve karbonhidrat oranı bulunmaktadır. Düşük Glisemik İndeks Diyeti 40-60 g/gün karbonhidrat (glisemik indeksi<50 olan besinler), \%60 yağ ve $\% 30$ proteinden; Modifiye Ketojenik Diyet ise \%5 karbonhidrat (yaklaşık 20-30 g/gün) ve \%75 yağlardan oluşmaktadır (7).

Ketojenik diyette; glikolizisten yağ asit oksidasyonuna büyük oranda bir geçiş olmakta, keton cisimleri ve yağ asitleri kanda ve beyinde artmaktadır. Oluşan keton cisimcikleri ( $\beta$-hidroksibütirat (BHB), asetoasetat ve aseton) kan-beyin bariyerini geçer ve beynin ana enerji kaynağı olurlar. Ketozis sırasında, beynin majör uyarıcı nörotransmitteri olan glutamatın, sinaptik salınımı artar ve gama-aminobütirik aside dönüşerek nöronal inhibisyona yol açar. Ketojenik diyet, keton cisimcikleri veya çoklu doymamış yağ asitleri (PUFA) yoluyla ATP üretimini arttırmakta ve serbest oksijen radikalleri üretimini azaltmaktadır. Her ikisinin de mitokondriyal bütünlüğü korumasina ve nöroprotektif etkiye sahip olmasına dair veriler giderek artmaktadır (8). Ayrıca, BHB'nin hem epigenetik hem de anti-inflamatuar aktivite oluşturduğu bildirilmektedir. MS’in deneysel hayvan modeli olan otoimmün ensefalomiyelitte (EAE) KD uygulamasıyla hastalığın ilerlemesinin yavaşladığı, motor engellilik ve hipokampal atrofinin iyileştiği, lezyonların tersine çevrildiği ve inflamatuvar sitokinler ile reaktif oksijen türlerinin baskılandığı gözlenmiştir (9). 
Ketojenik diyet, hem periferde hem de beyinde azalmış inflamasyon belirteçleri ile ilişkili motor ve bilişsel eksiklik üzerinde yararlı etkilere sahiptir (10). Özellikle oruç açlığına benzer diyetlerin; serolojik inflamasyonu azaltmada ve antioksidan yolakların düzenlenmesindeki etkileri aracılığıyla MS hastalarında potansiyel yarar sağlamaktadır (11). Prospektif gözlemsel bir çalışmada 6 ay süresince uygulanan ketojenik diyetin güvenilir olduğu ve hastaların yorgunluk ve depresyon düzeylerinde iyileşmeye yol açtığı sonucuna ulaşılmıştır (12).

Multipl sklerozda farmakolojik tedavilerin önemli yan etkileri olabileceğinden, spesifik diyet modelleri gibi tamamlayıcı tedavi seçeneklerine ihtiyaç duyulmuştur. Relapsing remitting MS (RRMS) hastaları ile yürütülen bir çalışmada, rastgele olarak üç gruba ayrıldıktan sonra üç farklı diyet modeli 18 ay boyunca uygulatılmıştır. Birinci gruba 20-40 g karbonhidratla sınırlı ketojenik diyet, ikinci gruba aralıklı açlık diyeti (her 6 ayda bir, 7 gün açlık ve 14 saatlik aralıklı açlık diyeti) ve üçüncü gruba yağ ile modifiye edilmiş standart diyet verilmiştir. Çalışma sonucunda ketojenik diyetin ve aralıklı açlık diyetinin bağışıklığı modüle edebileceği, hastalığın şiddetini azaltabileceği ve remiyelinizasyonu destekleyebileceği gözlenmiştir (13).

Başka bir randomize kontrollü çalışmada, hastalara 6 aylık süre boyunca modifiye Atkins diyeti uygulanmıştır. Çalışma süresince hastaların idrar ketonları, yorgunluk, depresyon skorları ve bazı biyokimyasal ve antropometrik verileri değerlendirilmiştir. Çalışma sonucunda hastaların yorgunluk ve depresyon düzeylerinin azaldığı saptanmıştır. Ayrıca hastaların açlık insülin, HbA1c ve trigliserit seviyelerinin de azaldığı gözlenmiştir. $\mathrm{Bu}$ durum KD’nin MS komorbiditeleri üzerinde yararlı etkisinin olduğunu göstermektedir. Ayrıca çalışma sonucunda; beden kütle indeksi (BKI) ile leptin seviyeleri arasında güçlü bir ilişkinin olmadığı, KD’nin leptinin düzenlenmesindeki etkisinin çok faktörlü olması sebebiyle adipozitedeki azalmayı tek başına sağlamadığı sonucuna ulaşılmıştır. Leptinin proinflamatuvar bir adipokin olması bu diyetlerin MS hastalığındaki olumlu etkisini immünolojik yolakla gösterdiğini de düşündürmektedir (11).

Multipl skleroz hastalarında sağlıklı bireylere göre insülin direncinin daha yaygın görüldüğü ve bu durumun daha yüksek Genişletilmiş Özürlülük Durumu Ölçeği (Kurtzke Expanded Disability Status Scale-EDSS) puanları ile ilişkili olduğu belirtilmektedir (14,15). Ayrıca artmış proinflamatuvar sitokin IL-17 serum düzeyleri, MS’de bozulmuş glikoz ve insülin metabolizmasını etkileyebilmektedir (16). MS hastalarında ortaya çlkan serebral glikoz hipermetabolizmasının, nöronal hücrelerde mitokondriyal disfonksiyonu yansıttığı düşünülmektedir $(17,18)$. Bu mekanizmanın nedeni henüz tam olarak anlaşılamamıştır. Ancak oksidatif stres tarafindan yönlendirilen nörodejeneratif süreçlerin mitokondriyal disfonksiyona neden olabileceği bildirilmektedir (19). Bu doğrultuda, fazla kilolu kadın ve erkeklerde 12 haftalık ketojenik diyetin, insülin direncini ve çeşitli serum inflamatuvar belirteçleri azalttığı saptanmıştır (20). Sonuç olarak, KD ve aralıklı açlık diyetleri karbonhidrat alımını büyük ölçüde azaltmakta, glikoz ve insülin seviyelerini düşürmektedir. Böylece ortaya çıan keton cisimcikleri demiyelinize aksonların rejenerasyonunu kolaylaştırabilmektedir (13).

\section{Swank Diyeti}

İlk kez 1950 yllında Roy L. Swank tarafından bir tedavi seçeneği olarak önerilmiştir. Az yağlı olan bu diyet, 10-15 g/gün doymuş yağ ve 20-40 g/gün doymamış yağ olmak üzere yağ tüketimini sınırlandırmaktadır (21). Swank diyetinde bireyin enerji ihtiyacına göre enerji miktarı belirlenmektedir. Bu diyet modelinde antiinflamatuvar etkiye sahip; 5 gram morina karaciğer yağı (A ve D vitamini, EPA, DHA), 10-15 gram balık yağı ve haftada $\geq 3$ kez balık tüketimi yer almaktadır. Ayrıca bu diyette tüketilmesi önerilen 45-250 g/gün taze meyve, 20-250 g/gün taze sebze, yağsız veya az yağlı süt ve süt ürünleri, tam tahıllar, kurubaklagiller, yumurta (sinırsız yumurta akı veya $\leq 3 \mathrm{kez} /$ hafta tam yumurta), $\leq 3$ fincan/gün kafeinli içeceklerin de antiinflamatuvar etkisi bulunmaktadır. 
Diyetin ilk yllında sığır eti ve organ eti tüketimi yasaklanmaktadır. Doymuş yağ içeriğinin yüksek olması nedeniyle işlenmiş besinlerden ve şekerli besinlerden (şeker,bal,jöle) kaçınılmasıistenmektedir. Ayrıca doymamış yağların oksidasyonunu önleyen antioksidan vitaminlerin ek olarak alınması (1000 mg C vitamini, 400 IU E vitamini) önerilmektedir (22).

Swank diyetinin takibini konu alan bir çalışmada, 144 MS hastası 34 yıl boyunca takip edilmiştir. Önerilen diyeti ( $\leq 20 \mathrm{~g}$ yağ/gün) uygulayanlarda belirlenenden daha fazla yağ tüketenlere (>20 g yağ/gün) göre nörolojik yetersizlikte daha az kötüye gitme ve daha düşük ölüm oranları saptanmıştır (23).

Gözlemsel bir çalışmada, 144 MS hastasının yaklaşık yarısının Swank diyetine güçlü bir şekilde uyum sağladığı belirtilmiştir. Diyete bir yıl boyunca uyum sağlayan grupta hastalığın tekrarlama oranı 1'den 0.3’e düşmüştür. Ayrıca bu gruptaki hastaların diyete 14 yıl güçlü uyum sağlamasıyla hastalığın tekrarlama oranının 0.05’in altına düştüğü rapor edilmiştir (12).

Swank tarafindan yapılan, 1953 ve 2003 yılları arasında yayınlanan araştırmalarda, toplam ve doymuş yağ oranı düşük diyet tüketen MS hastalarında diğer MS hastalarına kıyasla hastalığın engellilik düzeyinde azalma ve hayatta kalma sürelerinde artış olduğu belirtilmiştir (21). Randomize kontrollü bir çalışmada ise Swank diyeti uygulayan RRMS hastalarının yorgunluk düzeyi, BKI ve metabolik biyobelirteçlerinde anlamlı iyileşme saptanmıştır (24). Ancak bu diyetin MS hastaları üzerinde yararlı etkilerinin netlik kazanması için daha büyük örneklemde daha uzun süreli çalışmalara ihtiyaç vardir.

\section{Düşük Enerjili Diyetler}

Düşük enerjili diyetler, malnütrisyona yol açmadan toplam enerji alımının sürekli olarak azaltılmasıdır. Bu diyet modeli yaşayan organizmaların çoğunluğunda sağlığı ve yaşam süresini iyileştirmektedir. Düşük enerjilidiyetinveaçlığınfizyolojikvemoleküler etkileri bulunmaktadır. Fizyolojik olarak iyileşmiş yaşam kalitesi, vücut ağırlık kaybı, metabolik adaptasyon, kan basıncında, inflamasyon belirteçlerinde, açlık insülin düzeylerinde ve enerji harcamasında azalma oluşturmaktadır. Moleküler olarak oksidatif streste ve TNF-a'da azalma, otofajide artış, kardiyovasküler risk parametrelerinde azalma gibi etkileri bulunmaktadır (25).

Yemeklerden sonra tüketilen besinin türüne ve miktarına göre inflamasyon ve oksidatif stres oluşmaktadır. Postprandial inflamasyon artan enerji alımı, glisemik yük, doymuş yağ, trans yağ ve omega- 6 yağ asitleri ile artış göstermektedir. Buna karşın; polifenoller, omega-3 yağ asitleri, düşük enerjili diyet ve egzersiz postprandial inflamasyonu azaltmaktadır (26). MS hastalarında düşük enerjili diyet, yorgunluk düzeyinde azalma ve duygusal iyileşme gibi klinik yararlar göstermektedir (27).

Primer progresif MS hastaları üzerinde yapılan bir çalışmada, bir ay süresince Ramazan orucunu uygulayan hastaların yaşam kalitelerinde iyileşme olduğu saptanmıştır (12). Düşük enerjili diyet insanlarda sürdürülebilir bir diyet modeli gibi görünmemesi nedeniyle aralıklı açlık diyeti alternatif olarak öne çıkmaktadır. Alternatif gün açlık diyetleri, 5:2 aralıklı açlık diyeti (haftada 2 gün açlık), aralıklı enerji kısıtlaması (enerji alımında haftada 2 gün 500'er kkal azaltma), zaman kısitlı beslenme gibi farklı uygulama şekilleri bulunmaktadır (12). Aralıklı açlık diyeti; proinflamatuvar T-helper 17 (Th17) yanıtını baskılamakta, antiinflamatuvar düzenleyici $\mathrm{T}$ (Treg) hücrelerini indüklemekte ve mikrobiyotayı düzenleyerek MS üzerinde olumlu etki oluşturabildiği söylenmektedir (28).

Yapılan bir çalışmada RRMS hastalarının uyguladığı aralıklı açlık diyetinin lökosit apoptozunu indükleyerek MS'i baskıladığı ve hastaların yaşam kalitesini iyileştirdiği bildirilmiştir (29). Otuzaltı primer progresif MS hastası üzerinde yapılan bir çalışmada ise 8 hafta uygulanan enerji kısıtlı diyetin hastalarda duygusal iyileşme sağladığı belirtilmiştir (12). 


\section{Paleolitik Diyet}

Paleolitik diyet, sağlık üzerindeki olumlu etkilerinden dolayı son zamanlarda dünya çapında popülerlik kazanmıştır. Diyetin temel bileşenleri; yağsız et, balık, kabuklu yemişler, sebzeler, meyveler, yumurta gibi besinlerden oluşmaktadır (30).

Paleolitik diyet; B, D, E ve K vitamini, PUFA'lar, koenzim Q10, a-lipoik asit, polifenoller, karotenoidler, çinko ve selenyumdan zengindir. Polifenoller (meyveler, sebzeler, findık, çay, kırmızı şarap, alg, kahve, çikolata, zeytin ve zeytinyağı), karotenoidler (meyveler, sebzeler, zeytin, alg ve deniz ürünleri), PUFA (findık, tohum, zeytinyağı, deniz yosunu ve balık), D vitamini (balık ve karaciğer), selenyum (findık, balık ve deniz ürünleri) ve çinko (fındık ve tohum) inflamatuvar mediatörlerin ekspresyonunu baskılamakta ve oksidatif stresi azaltmaktadır. Ayrıca B vitamini (maya, karaciğer, sebze), E vitamini (kuruyemiş, yağlar, sebze ve meyveler), $\mathrm{K}$ vitamini (sebzeler ve karaciğer), ubiquinon (coenzim Q10; et, balık, sebze ve zeytinyağı) MS'de mitokondriyal mekanizma aracılığıyla beyin hücrelerini korumakta ve beynin rejeneratif potansiyelini desteklemektedir (31).

Primer Progresif MS hastaları üzerinde yapılan pilot bir çalışmada; paleolitik diyet uygulayan 9 hastadan 7'sinin yorgunluk düzeyinin iyileştiği bildirilmiştir (32). Randomize kontrollü bir çalışmada ise 17 primer progresif MS hastası 3 ay süresince paleolitik diyet uygulamıştır. Çalışma sonucunda hastaların \%65'inde yaşam kalitelerinin ve yorgunluk düzeylerinin iyileştiği sonucuna ulaşılmıştır (31). Başka bir çalışmada ise 20 primer progresif MS hastası 12 ay boyunca Paleolitik diyet uygulamış ve hastaların 11'inin yaşam kalitelerinin ve yorgunluk düzeylerinin iyileştiği saptanmıştır (12).

\section{Glutensiz Diyet}

Glutensiz diyetler temel olarak glutenin diyetten çıkarılmasına dayanmaktadır. Glutensiz diyetlerin temel ilkesi; buğday, arpa, çavdar, yulaf ve bu tahıllardan üretilmiş (nişasta, un, ekmek, makarna, kek vb.) ürünlerin eliminasyonunu sağlamaktır (33).

Yakın zamanda yapılan bir araştırmada, Amerikalı MS hastalarının \%5.55'inin glutensiz diyet uyguladığı ve bunların \%88'inde diyetin hastalık üzerinde olumlu etkisinin gözlendiği rapor edilmiştir (34). Aksine 42 MS hastası üzerinde yapılan bir çalışmada ise, 2 yıl boyunca uygulanan glutensiz diyetin hastalığın tekrarlama oranı ve engellilik düzeyine hiçbir etkisinin olmadığı belirtilmiştir (12).

Randomize klinik bir çalışmada ise, RRMS'li hastalar iki gruba ayrılmıştır. Birinci gruba glutensiz diyet verilirken, ikinci gruba herhangi bir diyet müdahalesinde bulunulmamıştır. İzlem süresi $5.3 \pm 1.6$ yll olan çalışma sonucunda hastaların EDSS engellilik skorları, lezyon aktiviteleri ve yıllık hastalık tekrarlama sayıları karşılaştırılmıştır. Glutensiz diyet uygulayan grupta lezyon aktiviteleri ve EDSS skorları daha düşük bulunmuştur (35). Prospektif bir çalışmada ise glutensiz diyet uygulayan hastaların \%50'sinde uygulamayan hastalara göre daha düşük EDSS skoru ve tekrarlama oranı olduğu bildirilmiştir (12).

Bazı çalışmalar glutensiz diyetin MS üzerinde olumlu etkisinin olduğunu gösterse de günümüzde MS hastalarında glutensiz diyetin etkileriyle ilgili herhangi bir kılavuz önerisi bulunmamaktadır (3).

\section{Bitkisel İçerikli Diyet}

Bitkisel içerikli diyetler (vegan ve vejetaryen diyetler dahil) içerdikleri bitkisel bileşenler aracılığıyla antiinflamatuvar etki oluşturmaktadır. Antioksidan polifenoller, karotenoidler ve posadan zengin bu diyet modeli, kısa zincirli yağ asitleri aracılığıyla antiinflamatuvar etki oluşturarak MS üzerinde olumlu etki sağlamaktadır (36).

Yapılan bir çalışmada, bir grup RRMS hastasına çok az yağlı bitkisel içerikli diyet müdahalesinde bulunulmuş diğer grup ise kontrolgrubu olarakizlenmiştir. Biryıllık izlem sonucunda gruplar arasında EDSS skorlarında, 
hastalık tekrarlama oranlarında ve beyin manyetik rezonans görüntülemelerinde anlamlı bir farklılık gözlemlenmemiştir. Ancak bitkisel diyet uygulayan grupta diğer gruba göre yorgunluk düzeylerinde, BKİ ve metabolik belirteçlerinde anlamlı bir iyileşme saptanmıştır (24). Primer progresif MS'li 25 ve 75 kontrol hastasının alındığı retrospektif bir çalışmada, fazla miktarda kırmızı et, hidrojenize yağ, şeker, az miktarda sebze içeren bir beslenme şekliyle MS oluşma riskinin vejetaryen diyete göre yaklaşık iki kat fazla olduğu rapor edilmiştir (12).

\section{Akdeniz Diyeti}

Akdeniz diyeti; zeytinyağı, sebze, meyve, kuruyemişler ve tam tahıllardan zengin, orta düzeyde balık, kümes hayvanları ve şarap, düşük miktarda süt ürünleri, kırmızı et ve şekerden oluşan bir diyet modelidir (12, 37).

Akdeniz diyeti piramidi tüketilmesi gereken besinlerin porsiyonlarını ve sıklıklarını belirtmektedir. Piramid bitkisel besinlerden zengin, hayvansal besinlerden fakir olması nedeniyle daha sağlıklı ve daha az çevresel etkiye sahiptir. Akdeniz diyetinde besinler tüketim sıklıklarına göre her öğün, her gün ve haftalık olarak sinıflandırılmaktadır. Aktif yaşam devamlılığı sağlamak ve vücut su dengesini korumak için günlük 1.5-2.0 litre su içilmelidir. Bu diyete göre ana öğünlerde; meyve (1-2 porsiyon), sebze ( $\geq 2$ porsiyon), zeytinyağı ve ekmek, pasta, pirinç, kuskus, diğer tahillar (tercihen tam tahil), patates (1-2 porsiyon) tercih edilmelidir. Her gün ise süt ürünleri (2 porsiyon), zeytin-kuruyemiş (1-2 porsiyon), baklagiller ve baharatlar, soğan ve sarımsak önerilmektedir. Ayrıca piramidde haftalık olarak; şeker ( $\leq 3$ porsiyon), kırmızı et ( $>2$ porsiyon), işlenmiş etler ( $\leq 1$ porsiyon), beyaz et ( 2 porsiyon), balık veya deniz ürünleri ( $\geq 2$ porsiyon) ve yumurta (2-4 porsiyon) tüketilmesi belirtilmiştir. Ayrıca Akdeniz diyetinde isteğe bağlı olarak, tercihen yemek sırasında, orta düzeyde (kadınlar 1 bardak/gün, erkekler 2 bardak/gün) şarap tüketimi yer almaktadır. Son olarak, piramidin en üstünde çok yağlı ve/veya çok şekerli tatlllar, hamur işleri ve içecekler küçük miktarda ve ara sıra tüketilmesi gerekmektedir (38).
Egzersiz ve sebzeler, meyveler, baklagiller, balık, prebiyotik ve probiyotikten zengin diyetler; proinflamatuvar moleküllerin sentezini azaltmakta ve sağlıklı simbiyotik bağırsak mikrobiyatasını yenilemekte ve devamlılığını sağlamaktadır. Bu antiinflamatuvar bileşenler (egzersiz ve diyet) MS'de kronik yorgunluk semptomlarını iyileştirerek sağlıklı yaşamı desteklemektedir (39). İran'da yapılan vaka kontrol çalışmasında, 142 kontrol ve 70 MS hastası çalışmaya dahil edilmiştir. Bireylerin Akdeniz diyeti uyumunu değerlendiren ölçek kullanılmış ve yüksek Akdeniz diyetine uyum ile düşük MS riski arasında ilişki bulunmuştur (40). Hemşire Sağlık Çalışması'nda ise 480 MS hastasına Akdeniz Diyet İndeksi uygulatılmış ve Akdeniz diyetine bağlılık ile MS riski arasında hiçbir ilişki saptanmamıştır (12).

Akdeniz diyeti ile birlikte artan polifenoller, flavonoidler ve tanenler MS üzerinde yararlı etki oluşturmaktadır (12). Diyet polifenolleri; meyveler, sebzeler, tahıllar, baklagiller, baharatlar, şarap, meyve suları, çay ve kahveden elde edilmektedir. Polifenoller yapısal olarak kuarsetin gibi flavonoidler ve resveratrol gibi flavonoid olmayanlar olarak sinıflandırılmaktadır. Polifenoller, proinflamatuar etki gösteren nükleer transkripsiyon faktör $\kappa B$ (NF-kB)'nin aktivitesini baskılayarak ve doğrudan antioksidan etki yoluyla bağışıklığı etkilemektedir. Günümüze kadar MS hastalarında polifenol takviyesinin etkisine dair herhangi bir çalışma yapılmamış olup, MS modellerinde klinik öncesi sonuçlar karşılaştırılmıştır. Yeşil çay polifenolü olan epigallokateşin 3 gallat, otoimmün ensefalomiyeliti (EAE)'yi iyileştirmek için yeterli olmuştur. Bu polifenol düşük proinflamatuvar sitokin üretimi ve myelin peptidine karşı azalmış $\mathrm{T}$ hücre proliferasyonu ile ilişkili bulunmuştur. Apigenin, hesperidin ve kuarsetin içeren doğal flavonoidlerin bağışıklık yanıtı modüle ederek EAE’ye karşı koruma sağladığı da gösterilmiştir. Resveratrolün klinik öncesi MS modelinde remiyelinizasyonu desteklediği bildirilmiştir. Ancak resveratrolün virüs kaynaklı klinik öncesi MS modellerinde ve EAE'de hastalığı alevlendirdiği de gözlenmiştir. Buna 
ek olarak bir çalışmada kuarsetinin EAE'yi hafif düzeyde iyileştirdiği, başka bir çalışmada ise EAE’yi şiddetlendirdiği bulunmuştur (28).

Akdeniz diyetindeki meyveler, sebzeler ve tam tahıllar iyi bir posa kaynağıdır. Posanın antioksidan (karotenoidler,polifenoller)özelliğideMSönlemederol oynayabilir (40). İnülin ve galaktooligosakkaritler gibi posalar dirençli nişasta ve oligosakkaritleri içermekte olup, kolonik bakteriler tarafindan metabolize edilmektedir. Bakteriler için bir subsrat olan yüksek posa miktarı, bağırsak mikrobiyatasını değiştirebilir ve tolerojenik kommensal bakterilerin büyümesini destekleyebilir. Ayrıca posa antiinflamatuvar özelliklere sahip bakteriler tarafindan kısa zincirli yağ asitlerine (SCFA) fermente edilebilir. Posa takviyesinin EAE'yi iyileştirmesinin değişmiş barsak mikrobiyatası ve artmış bağırsak SCFA'ları ile ilişkili olduğu gözlenmiştir. MS hastalarında diyet posası takviyesinin etkilerini incelemek için yapılmış bir çalışma bulunmamaktadır. Ancak posa açısından zengin besin tüketiminin MS hastalarına yarar sağlayabileceğini gösteren kanıtlar bulunmaktadır (28).

\section{SONUÇ VE ÖNERILER}

Beslenme MS patogenezinde olası bir faktör olarak kabul edilir. Ancak günümüzde MS hastaları için önerilen özel bir diyet modeli bulunmamaktadır. MS hastaları için güncel sağlıklı beslenme kılavuzları enerjinin yeterli, makro (karbonhidrat, yağ, proteinler) ve mikro besin ögeleri (vitamin ve mineraller) oranlarının dengeli olmasını önermektedir. Esansiyel yağ asitlerinin, rafine edilmemiş karbonhidratların (yorgunluk ve halsizlik gibi semptomları hafifletmek için), antioksidanların, $D$ ve $B_{12}$ vitamininin plazma seviyeleri artırılmalıdır. Ayrıca yeterli protein, çinko, posa ve sıvı (düzenli bağırsak hareketleri için) alınması sağlanmalıdır. Diyet MS hastalarında geleneksel bir tedavi yöntemi değildir. Ancak sağlıklı beslenme müdahalesi MS hastalarınin fiziksel ve zihinsel engelliliği azaltmakta ve yaşam kalitesini iyileştirmektedir. Ayrıca uygun diyet müdahalesi inflamatuvar yanıt derecesini etkileyerek hastalık seyrini iyileştirebileceğinden hastalıkta olası tamamlayıcı tedavi olarak düşünülmektedir.

Yazarlık katkısı - Author contributions: Çalışmanın tasarımi: BK, SB; İlgili literatürün taranması: BK; Makale taslağının oluşturulması: BK; Içerik için eleştirel gözden geçirme: $S B$; Yayınlanacak versiyonun son onayl: $B K, S B . \cdot$ Study design: BK, SB; Literature review: BK; Draft preparation: $B K$; Critical review for content: $S B$; Final approval of the version to be published: $S B$.

Çıkar çatışması - Conflict of interest: Yazarlar çıkar çatışması olmadığın beyan ederler. - The authors declare that they have no conflict of interest.

\section{KAYNAKLAR}

1. Ochoa-Morales A, Hernandez-Mojica T, Paz-Rodriguez F, Jara-Prado A, Trujillo-De Los Santos Z, Sánchez-Guzmán MA, et al. Quality of life in patients with multiple sclerosis and its association with depressive symptoms and physical disability. Mult Scler Relat Disord. 2019;36:101386.

2. Thomsen HL, Jessen EB, Passali M, Frederiksen JL. The role of gluten in multiple sclerosis: A systematic review. Mult Scler Relat Disord. 2019;27:156-7.

3. Waubant E, Lucas R, Mowry E, Graves J, Olsson T, Alfredsson L, et al. Environmental and genetic risk factors for MS: An integrated review. Ann Clin Transl Neurol. 2019;6(9):1905-17.

4. Demir A, Ylldız E. Multiple skleroz ve beslenme. Ortadoğu Tip Dergisi. 2015;7(3):144-8.

5. Pizzorno JE, Murray MT. Textbook of Natural Medicine. 5th ed. China: Elsevier; 2021. 1587-11 p.

6. Barry D, Ellul S, Watters L, Lee D, Haluska R Jr, White R. The ketogenic diet in disease and development. Int J Dev Neurosci. 2018;68:53-8.

7. Husari KS, Cervenka MC. The ketogenic diet all grown up ketogenic diet therapies for adults. Epilepsy Res. 2020;162:106319.

8. Karabulut Ş. Ketojenik diyet ve kalori kısıtlı diyetin antiinflamatuvar etkilerinin incelenmesi [Uzmanlık Tezi]. Marmara Üniversitesi Tıp Fakültesi, İstanbul; 2019.

9. Kim DY, Hao J, Liu R, Turner G, Shi FD, Rho JM. Inflammation-mediated memory dysfunction and effects of a ketogenic diet in a murine model of multiple sclerosis. PLoS One. 2012;7(5):e35476.

10. Koh S, Dupuis N, Auvin S. Ketogenic diet and neuroinflammation. Epilepsy Res. 2020;167:106454. 
11. Brenton J, Banwell B, Bergqvist C, Lehner-Gulotta D, Leytham E, Gampper L, et al. Application of a modified ketogenic diet in relapsing-remitting multiple sclerosis subjects. J Acad Nutr Diet. 2019;119(1):A19.

12. Evans E, Levasseur V, Cross AH, Piccio L. An overview of the current state of evidence for the role of specific diets in multiple sclerosis. Mult Scler Relat Disord. 2019;36:101393.

13. Bahr LS, Bock M, Liebscher D, Bellmann-Strobl J, Franz L, Prüß A, et al. Ketogenic diet and fasting diet as Nutritional Approaches in Multiple Sclerosis (NAMS): Protocol of a randomized controlled study. Trials. 2020;21(1):3-12.

14. Oliveira SR, Kallaur AP, Lopes J, Colado Simao AN, Reiche EM, de Almeida ERD, et al. Insulin resistance, atherogenicity, and iron metabolism in multiple sclerosis with and without depression: Associations with inflammatory and oxidative stress biomarkers and uric acid. Psychiatry Res. 2017;250:113-7.

15. Oliveira SR, Simao AN, Kallaur AP, de Almeida ER, Morimoto HK, Lopes J, et al. Disability in patients with multiple sclerosis: Influence of insulin resistance, adiposity, and oxidative stress. Nutrition. 2014;30(3):2685.

16. Zuniga LA, Shen WJ, Joyce-Shaikh B, Pyatnova EA, Richards AG, Thom C, et al. IL-17 regulates adipogenesis, glucose homeostasis, and obesity. J Immunol. 2010;185(11):6947-12.

17. Blinkenberg M, Jensen CV, Holm S, Paulson OB, Sorensen PS. A longitudinal study of cerebral glucose metabolism, MRI, and disability in patients with MS. Neurology. 1999;53(1):149-4.

18. Tenney JR, Rozhkov L, Horn P, Miles L, Miles MV. Cerebral glucose hypometabolism is associated with mitochondrial dysfunction in patients with intractable epilepsy and cortical dysplasia. Epilepsia. 2014;55(9):1415-7.

19. Storoni M, Plant GT. The therapeutic potential of the ketogenic diet in treating progressive multiple sclerosis. Mult Scler Int. 2015;2015:681289.

20. Forsythe CE, Phinney SD, Fernandez ML, Quann EE, Wood RJ, Bibus DM, et al. Comparison of low fat and low carbohydrate diets on circulating fatty acid composition and markers of inflammation. Lipids. 2008;43(1):65-13.

21. Swank RL, Goodwin J. Review of MS patient survival on a swank low saturated fat diet. Nutrition. 2003;19(2):1612.

22. Wahls TL, Chenard CA, Snetselaar LG. Review of two popular eating plans within the multiple sclerosis community: Low saturated fat and modified paleolithic. Nutrients. 2019;11(2):352-32.
23. Swank RL, Dugan BB. Effect of low saturated fat diet in early and late cases of multiple sclerosis. The Lancet. 1990;336(8706):37-3.

24. Yadav V, Marracci G, Kim E, Spain R, Cameron M, Overs S, et al. Low-fat, plant-based diet in multiple sclerosis: A randomized controlled trial. Mult Scler Relat Disord. 2016;9:80-90.

25. Madeo F, Carmona-Gutierrez D, Hofer SJ, Kroemer G. Caloric restriction mimetics against age-associated disease: Targets, mechanisms, and therapeutic potential. Cell Metab. 2019;29(3):592-610.

26. Altowaijri G, Fryman A, Yadav V. Dietary interventions and multiple sclerosis. Curr Neurol Neurosci Rep. 2017;17(3):28.

27. Roman SN, Fitzgerald KC, Beier M, Mowry EM. Safety and feasibility of various fasting-mimicking diets among people with multiple sclerosis. Mult Scler Relat Disord. 2020;42:102149.

28. Sanchez JMS, DePaula-Silva AB, Libbey JE, Fujinami RS. Role of diet in regulating the gut microbiota and multiple sclerosis. Clin Immunol. 2020;7:108379.

29. Choi IY, Piccio L, Childress P, Bollman B, Ghosh A, Brandhorst S, et al. A diet mimicking fasting promotes regeneration and reduces autoimmunity and multiple sclerosis symptoms. Cell Rep. 2016;15(10):2136-46.

30. Lavie M, Lavie I, Maslovitz S. Paleolithic diet during pregnancy-A potential beneficial effect on metabolic indices and birth weight. Eur J Obstet Gynecol Reprod Biol. 2019;242:7-11.

31. Irish AK, Erickson CM, Wahls TL, Snetselaar LG, Darling WG. Randomized control trial evaluation of a modified Paleolithic dietary intervention in the treatment of relapsing-remitting multiple sclerosis: A pilot study. Degener Neurol Neuromuscul Dis. 2017;7:1-18.

32. Bisht B, Darling WG, Grossmann RE, Shivapour ET, Lutgendorf SK, Snetselaar LG, et al. A multimodal intervention for patients with secondary progressive multiple sclerosis: Feasibility and effect on fatigue. J Altern Complement Med. 2014;20(5):347-55.

33. Ulusoy HG, Rakıcıoğlu N. Glutensiz diyetin sağlık üzerine etkileri. Bes Diy Derg. 2019;47(2):87-92.

34. Fitzgerald KC, Tyry T, Salter A, Cofield SS, Cutter G, Fox RJ, et al. A survey of dietary characteristics in a large population of people with multiple sclerosis. Mult Scler Relat Disord. 2018;22:12-8.

35. Rodrigo L, Hernández-Lahoz C, Fuentes D, Mauri G, Alvarez N, Vega J, et al. Randomised clinical trial comparing the efficacy of a gluten-free diet versus a regular diet in a series of relapsing-remitting multiple sclerosis patients. Int J Neurol Neurother. 2014;1:1-6. 
36. Esposito S, Bonavita S, Sparaco M, Gallo A, Tedeschi G. Role of diet in regulating the gut microbiota and multiple sclerosis. Nutr Neurosci. 2018;21(6):377-90.

37. Bach-Faig A, Beryy EM, Lairon D, Reguant J, Trichopoulou A, Dernini S, et al. Mediterranean Diet Foundation Expert Group. Mediterranean diet pyramid today. Science and cultural updates. Public Health Nutr. 2011;14(12A):2274-84.

38. Serra-Majem L, Tomaino L, Derdini S, Berry EM, Lairon D, de la Cruz JN, et al. Updating the Mediterranean diet pyramid towards sustainability: focus on environmental concerns. Int J Environ Res Public Health. 2020;17(23):8758.

39. Riccio P, Rossano R. Nutrition facts in multiple sclerosis. ASN Neuro. 2015;7(1):1759091414568185.

40. Sedaghat F, Jessri M, Behrooz M, Mirghotbi M, Rashidkhani B. Mediterranean diet adherence and risk of multiple sclerosis: A case-control study. Asia Pac J Clin Nutr. 2016;25(2):377-84. 